\title{
重ね継手を有するハーフプレキャスト柱に関する研究 PRECAST REINFORCED CONCRETE COLUMN USING LAP SPRICES
}

\author{
增田安彦*, 吉岡研三** \\ Yasuhiko MASUDA and Kenzoh YOSHIOKA
}

\begin{abstract}
New construction methods have been developed to save labor and wood resources at construction sites and shorten construction periods of reinforced concrete buildings. The joint method is a type of lap splice, in which main bars are butted together at the midheight of the column and reinforced with small-diameter splint bars. These splint bars are contained in a precast concrete shell form (PCa-shell) for columns.

The results of structural experiments on reinforced concrete members which have been designed by this method are explained in this paper. It appeared that the tie bars, which were installed in the PCa-shell, improved structural performance and that shear and flexural strengths were the same as with non-spliced PCa-shell members. Bond design methods for this joint type are further proposed.
\end{abstract}

Keywords : reinforced concrete, column, precast concrete, lap sprices, shear-flexual experiment 鉄筋コンクリート，柱，外款プレキャストコンクリート，重ね継手，曲げせん断実験

\section{1. 序論}

現在、建築工事の大型化、高層化が進む傍ら、建設現 場における技能工不足や高路化は年々深刻さを增してい る。このような背景から RC 建物では部材のプレキャス 卜化が推進され、様々なプレキャスト工法が考案・開発 されている。特に柱、梁、耐震壁等を部材ごとに製作し、 建設現場にて接合する方式が主流であるが、部材同士の 接合方法をいかに簡単に信頼性の高いものにするかがこ の工法の最も重要な検討項目になる。近年その接合を簡 単にするため部材の外殼部分をプレキャスト化し、鉄筋 継手に通常の圧接や重ね継手を用いる施工法が增加しつ つある。

筆者らは施工が容易で天候に左右されない重ね継ぎ手 に着目し、添え筋を用いて太径異形鉄筋の重ね継手部を 補強した場合の部材の耐力性状について検討した1)。し かしながら柱部材に通常の重ね継手を用いる場合、主筋 位置が上階と下階で異なるため、柱主筋ばかりでなく梁 主筋の位置も各階ごとにずれたり、かふりコンクリート 厚さを確保するために断面が大きくなるなど、設計上あ
るいは施工上の問題が生じる。これらの問題を解決する ため、図 1 に示すような、主筋を重ねることなく柱部材 の内のりスパンの中央で突合せ、同時に内のりスパンに 主筋より細径の添え筋を配して、主筋と添え筋の重ね継 手により応力を 伝達する突合せ 式重ね継手（以 後突合せ継手と 省略する）を考 案し、これを外 殸プレキャスト コンクリート管 (以後 $\mathrm{PCa}$ 管と 省略する）を用 いる、いわゆる ハーフPCa工法 に採用し、より 建築生産性の向 上をねらった

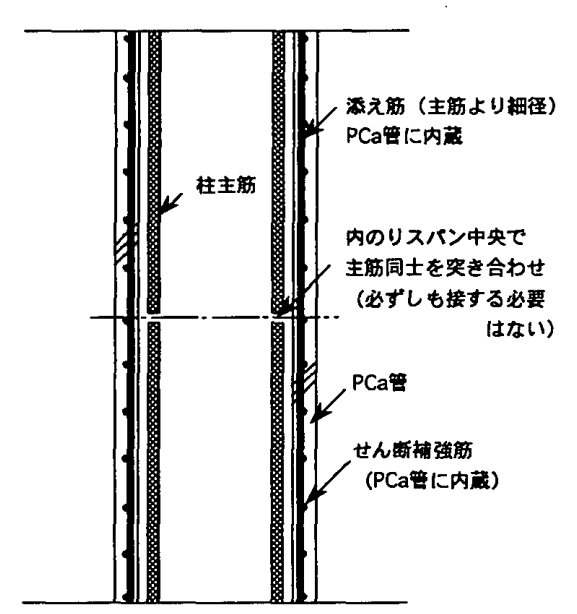

図 1 工法の概要

\footnotetext{
* 陎大林組技術研究所 研究員

** 侏大林組技術研究所 研究室長.工博
}

Research Engineer, Technical Research Institute of Obayashi Corporation

Maneger, Technical Research Institute of Obayashi Corporation., Dr. Eng. 
2)377) 9)。なお、柱内のりスパンに配する重ね鉄筋は、一 種の主筋であるがここでは区別のため添え筋と称してい る。

本論文は、带筋・添え筋をPCa管に内蔵させて使用し、 突合せ継手を用いた柱部材（図1）を主な対象として、部 村の耐力・変形性状、応力伝達機構の解明を試み、設計 法を確立することを目指したものである。

\section{2. 曲け゚ せん断実験}

\section{1 実験目的}

比較的短い柱が逆対称曲げモーメントを受けせん断ひ びわれが生じると、主筋応力は部材中央でゼロにならな い4)。この現象は、せん断力を負担するアーチ機構の反 カやトラス機構におけるコンクリートの圧縮束の水平成 分の一部が主筋に作用するためと推定される。そのため 突合せ継手部材のスパン中央断面では添え筋に応力が生 し、主筋応力を伝達するためには 添光筋量の検討も必要となること が予想される。

実験は主筋・添え筋のひずみ分 布あるいは添之筋の補強効果、部 材の付着割裂耐力に及ほす様々な 影響を捕え、主筋同士の突合せ位 置が部材の内のりスパン中央から 離れた位置にある場合も含めて、 突合せ継手部材の耐力・付着性状 を明確にすることを目的とした。

\section{2 実験概要}

実験は実大試験体

(小型試験体)

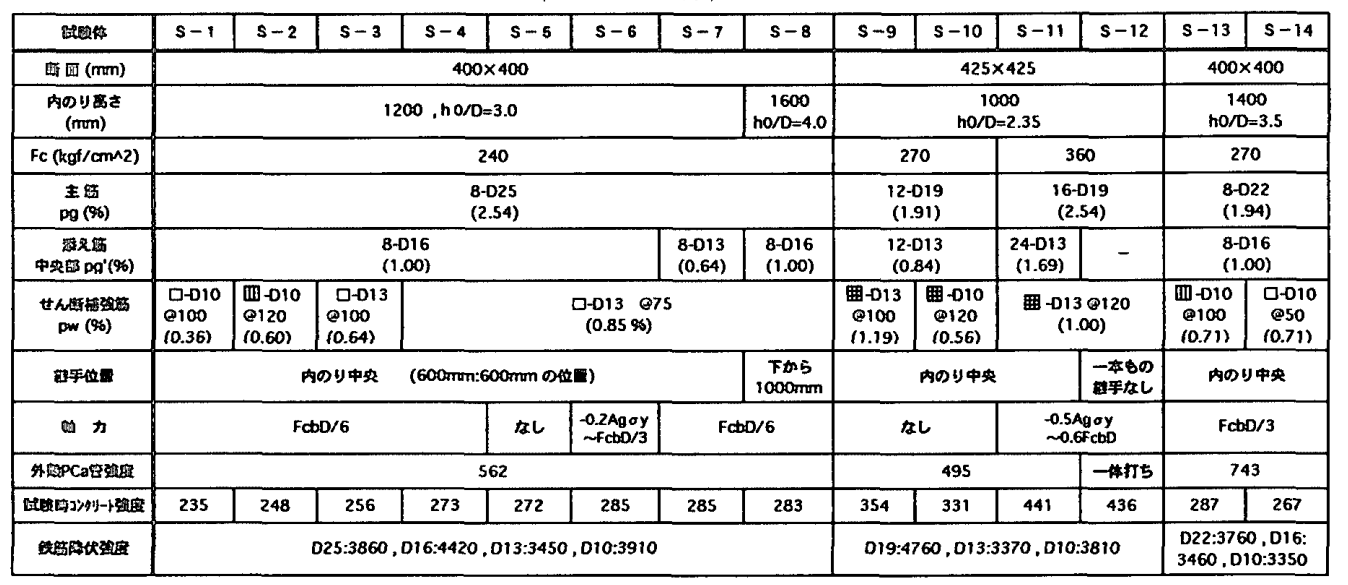
13体と、約 $1 / 2$ スケー ルの小型試験体 14 体 の合計27体からなっ ている。試験体の概 要および使用材料を 表 1 に示す。

実大試験体は主筋 に太径鉄筋を用いて おり、パラメータに 主筋径、添之筋量、 せん断補強筋量、軸

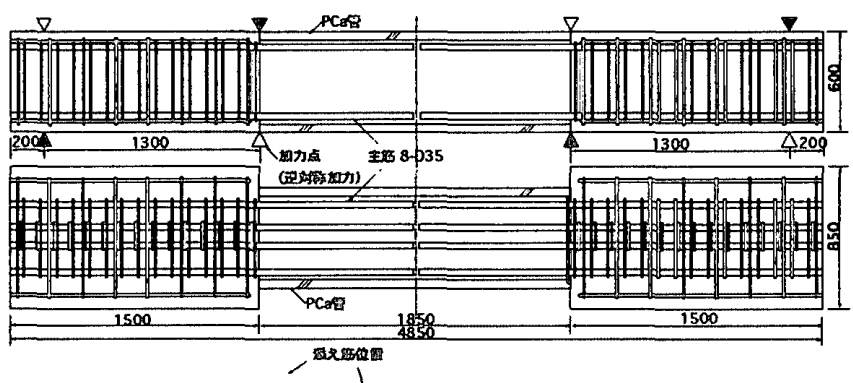

$160,165+150,165,1601$
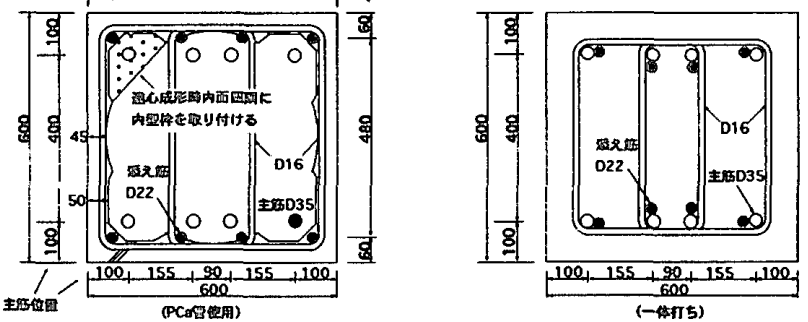

図 2 (a) 試験体断面・形状 (L-1 L L-13)
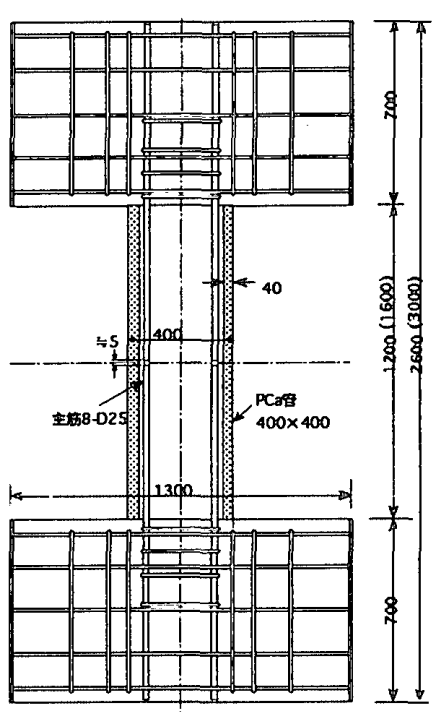
力、およびPCa管使用の有無 を取り上げた。主筋の突き合 わせ位置はすべて内のりスパ ンの中央とし、添え筋は内の りスパン全長に配置した。添 之筋量は主筋のない部材中央 でpg'=0.88以上となることを 基準としている。PCa管は遠 心成形によって製造した薄肉 の中空角型高強度コンクリー 卜管5)で、带筋、副带筋（中 子筋）、添え筋を内蔵させ、 内部隅角部にはシアコッター

(" $100 \times{ }^{1} 50 \times{ }^{\mathrm{h}} 5 \mathrm{~mm}$ @ 950 8箇所)を設けた。 小型試験体は主筋の量および径、添え筋量、 せん断補強筋量、軸力、コンクリート強度、突 合せ位置を変数に取り上げた。せん断補強筋は その量 (pw) と形状すなわち副帯筋の有無もパラ メータとした。また、軸力比は変動軸力、軸力 なしを含め 4 タイプとした。主筋の突合せは 1 体を除き内のり中央とし、ほほ主筋同士が接す る程度に、他の 1 体は内のりを5:4に内分する位 置とした。図 2 に試験体の断面・形状の一例を 示す。

載荷はいずれも变位制御とし、個々の部材角 で各 2 回繰返す正負交番繰返し載荷とした。

\section{3 実験結果}

\subsection{1. 破罗・耐力性状}

\section{(1) 実大試験体}

表 2 に実験結果の一覧を示す。実大試験体の 内L-8，L-9, L-10を除くすべての試験体が部材角 $\mathrm{R}=1 / 50$ 以上でも酎力が低下しない鞀性的な破壊 を生じた。L-8, L-9, L-10は主筋降伏が生じる直 前あるいは降伏とほは同時に付着割裂破壊を生 ビた。図 3 (a)に試験体に作用するせん断力と 層間変位の関係 $(\mathrm{Q}-\delta$ 関係) の一例を $\mathrm{PCa}$ 管 の使用の有無を比較し、図 3 (b)にその他の試 験体の包絡線図を示す。曲け破壊を生じた試験 体ではPCa管を使用した試験体の降伏および最 大耐力は使用しない場合に比べ同等以上の值を 示し、 $\mathrm{Q}-\delta$ 曲線もより大きなループを描いて いるが、付着破壊を生じた場合、逆にPCa管を 用いた方が耐力性状が悪いと言える。

$\mathrm{L}-1, \mathrm{~L}-2, \mathrm{~L}-3$ は主筋曲げ降伏後、変位 $\mathrm{R}=1 / 50$ 前後で部 材中央部で添え筋の曲げ降伏を生じ、 $\mathrm{R}=1 / 40$ をピークに 比較的䩓性的な耐力低下を示した。このことから、添え 筋が降伏すると2.1節で述べたトラス機構が成立しない一 種のせん断破壊が生じるものと推定される。
表 2 実大試験体実験結果一欄

\begin{tabular}{|r|r|r|r|r|r|r|r|r|r|r|r|}
\hline & $\mathrm{L}-3$ & $\mathrm{~L}-4$ & $\mathrm{~L}-5$ & $\mathrm{~L}-8$ & $\mathrm{~L}-7$ & $\mathrm{~L}-8$ & $\mathrm{~L}-8$ & $\mathrm{~L}-10$ & $\mathrm{~L}-11$ & $\mathrm{~L}-12$ & $\mathrm{~L}-13$ \\
\hline 5 & 354 & 307 & 315 & 419 & 369 & 310 & 370 & 337 & 302 & 267 & 328 \\
\hline 0 & 17.5 & 14.6 & 51.2 & 61.8 & 42.6 & 17.5 & 29.2 & 23.4 & 35.0 & 52.6 & 46.7 \\
\hline & 35.0 & 35.0 & 70.1 & 87.6 & 105.1 & 46.7 & 46.7 & 46.7 & 40.9 & 58.6 & 75.9 \\
\hline 3 & 55.4 & 80.8 & 102.2 & 125.9 & 109.3 & 77.3 & - & - & 76.0 & 105.3 & 105.3 \\
\hline 5 & 1.28 & 1.36 & 1.19 & 1.11 & 1.17 & 1.29 & - & - & 1.17 & 1.20 & 1.13 \\
\hline & 99.9 & 109.9 & 139.5 & 171.0 & 141.5 & 77.3 & 69.7 & 65.2 & 89.0 & 128.1 & 128.2 \\
\hline & 72.3 & 68.2 & 96.0 & 120.5 & 110.0 & 68.4 & 74.8 & 74.8 & 74.8 & 96.3 & 101.9 \\
\hline & 164.2 & 196.6 & 240.8 & 290.0 & 256.9 & 150.1 & 159.8 & 133.6 & 162.6 & 209.1 & 218.8 \\
\hline & - & - & - & - & - & - & - & 57.2 & - & - & - \\
\hline & 1.38 & 1.61 & 1.45 & 1.42 & 1.29 & 1.13 & 0.93 & 1.14 & 1.19 & 1.33 & 1.26 \\
\hline
\end{tabular}
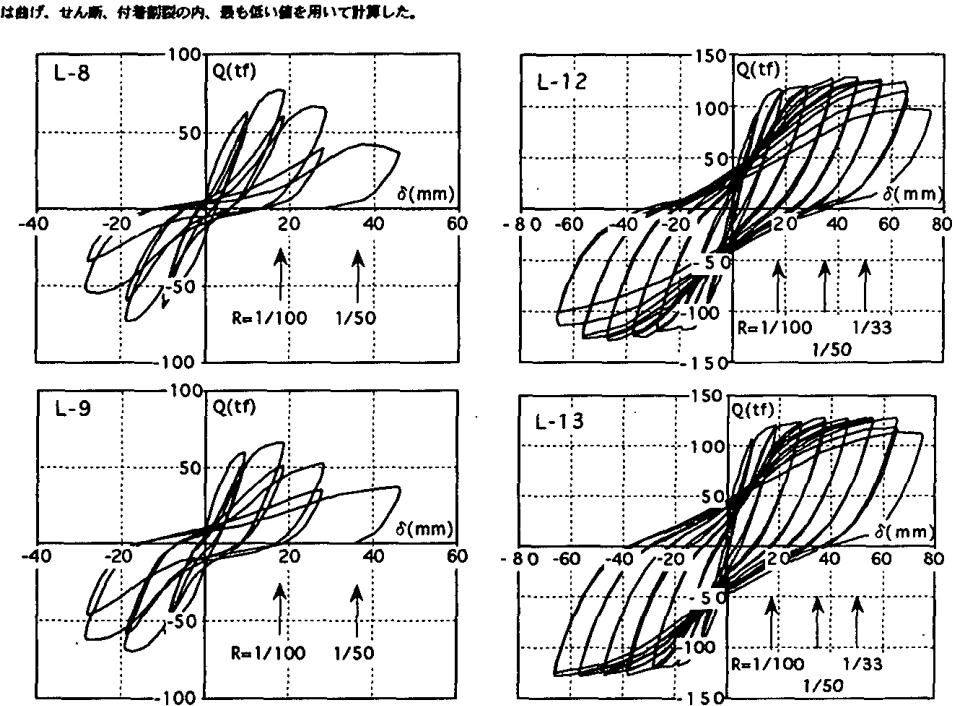

図 3 (a) 付着破壊と曲げ破壊の $\mathrm{Q}-\delta$ 関係一例 上段がR C下段が P C a 試験体
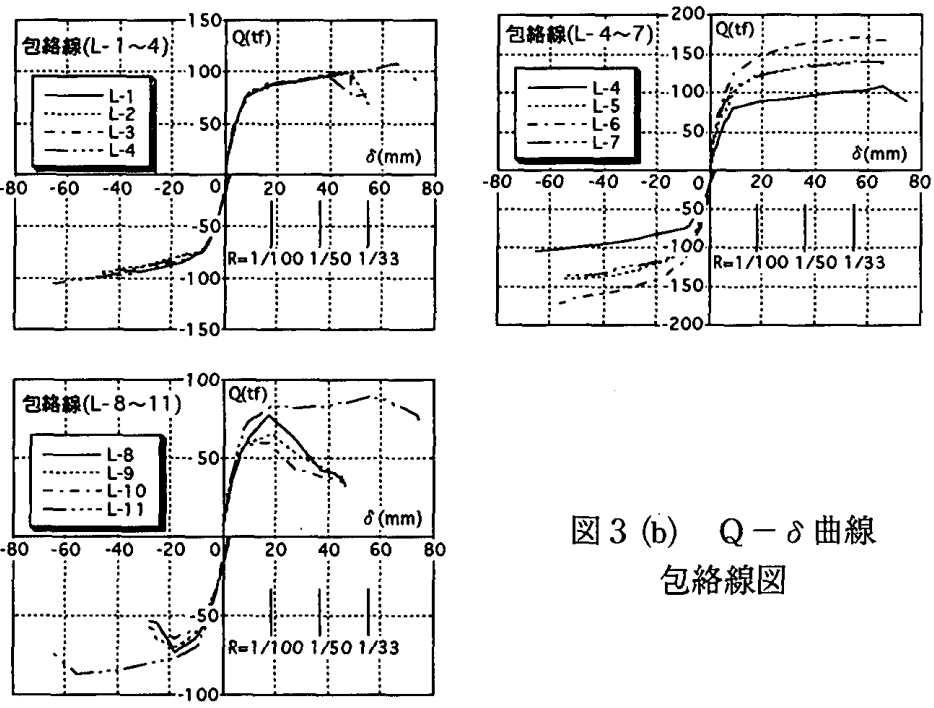

図 3 (b) $\mathrm{Q}-\delta$ 曲線 包絡線図

せん断補強筋量 (pw) が異なるL-2、4、8を比較すると、 pw=2.0\%で曲け破㐭、1.3\%で添え筋降伏破壊、0.8\%で付着 割裂破壤となり、せん断補強筋が少ない場合にはせん断 破壊が生じることも予想され、破壤性状は 4 種に大別さ れること、せん断補強筋量が破壊性状に及ほす影響が大 
きいことが分かる。

(2)小型試験体

表 3 に実験結果の一覧 を示す。小型試験体は実 大試験体に比へ比較的せ 儿断補強笳量が少ないた め、14体中 8 体が主筋 降伏に前後して付着破液 を生じた。曲け降伏前に 付着破壊を生じた 5 体の 試験体は、せん断補強笳 に副帯筋を使用せず、外 周筋のみで補強したも ので、PCa管とコアコン クリートの一体性が比 較的早期に失われたことが原因と推定され、後 述する特有の割裂パターンによる破壊が考えら れる。また、図 $4(\mathrm{a}) に \mathrm{Q}-\delta$ 関係を比較した 例を、図 4 (b)では断面およびho/Dが等しい試 験体の包絡線を、図 4 (c) はその他の試験体の $\mathrm{Q}-\delta$ 関係を示す。S-1Ｓ-7 試験体はいずれ も部材角 $R=1 / 100 \sim 1 / 50$ 程度で最大耐力に達 し、その後脆性的な耐力低下を示すこと、Q$\delta$ 曲線はエネルギー吸収能力にそしく原点指向 型であることか特徽である。また、部材角 $\mathrm{R}=1$ / 100以降は柱主筋の抜け出しによると推定され る変形を生じており、これを拘束するせん断補 強筋の量が多い試験体ほど変形能力が大きい傾 向が見られる。S-2試験体は曲げ降伏後にせん 断補强筇が降伏し、荷重か低下したため、表 3 ではせん断破壞としたが、付着とせん断による 複合的な破壊と思われる。この試験体の最大耐 力時の変形量および $\mathrm{Q}-\delta$ 曲線は、前述の付着 破壊を生じた試験体とあまり変わらないが、最 大酎力は同一軸力でせん断補強筋の多いS 3,S-4よりも高い。

さらに図4(a)に示すように、同一pwのS13,S-14を比較すると明らかに副帯筋を有する
表 3 小型試験体実験結果一覧

\begin{tabular}{|c|c|c|c|c|c|c|c|c|c|c|c|c|c|c|c|c|c|c|}
\hline \multicolumn{2}{|c|}{ totet } & \multirow{2}{*}{\begin{tabular}{r|}
$s-1$ \\
239
\end{tabular}} & \multirow{2}{*}{$\frac{s-2}{277}$} & \multirow{2}{*}{$\frac{s-3}{264}$} & \multirow{2}{*}{$\frac{s-4}{256}$} & \multirow{2}{*}{\begin{tabular}{|c|}
$s-5$ \\
226
\end{tabular}} & \multicolumn{2}{|c|}{$s-6$} & \multirow{2}{*}{\begin{tabular}{|c|}
$s-7$ \\
224
\end{tabular}} & \multirow{2}{*}{$\begin{array}{r}s-8 \\
130\end{array}$} & \multirow{2}{*}{$\frac{s-9}{189}$} & \multirow{2}{*}{\begin{tabular}{r|}
$s-10$ \\
190
\end{tabular}} & \multicolumn{2}{|c|}{$s-11$} & \multicolumn{2}{|c|}{$s-12$} & \multirow{2}{*}{$\frac{s-13}{193}$} & \multirow{2}{*}{$\frac{s-14}{154}$} \\
\hline Swat & $\mathrm{t} / \mathrm{cm}$ & & & & & & 228 & & & & & & 439 & - & 490 & & & \\
\hline 田办 & $\operatorname{ven}$ if & 11.0 & 9.0 & 16.0 & 11.2 & 4.0 & 26.0 & -6.0 & 18.0 & 5.0 & 30.0 & 26.0 & 60.0 & -13.5 & 53.0 & -10.0 & 19.1 & 21.2 \\
\hline \multicolumn{2}{|c|}{ 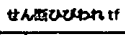 } & 44.0 & 42.0 & 44.0 & 43.0 & 28.0 & 56.0 & -20.0 & 42.0 & 30.0 & 32.0 & 36.0 & 66.0 & -28.0 & 62.0 & -15.0 & 41.3 & 39.8 \\
\hline \multirow{3}{*}{\begin{tabular}{|l|} 
\\
a \\
w \\
$\mathbb{1}$ \\
tf \\
\end{tabular}} & 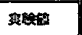 & - & 57.1 & - & - & 40.9 & - & -36.2 & - & 42.9 & 41.8 & 41.4 & 64.4 & -31.8 & 76.0 & -42.0 & 53.5 & $\$ 2.4$ \\
\hline & 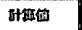 & 54.5 & 54.5 & 54.5 & 54.5 & 39.4 & 68.1 & -32.1 & 54.4 & 40.8 & 38.4 & 44.5 & 120.0 & \begin{tabular}{|l|}
-33.4 \\
\end{tabular} & 118.9 & -32.1 & 47.5 & 47.5 \\
\hline & 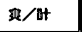 & - & 1.05 & - & - & 1.04 & - & 1.13 & - & 1.05 & 1.09 & 0.93 & $(0.54)$ & 0.95 & (0.64) & 1.31 & 1.13 & 8.10 \\
\hline \multirow{5}{*}{ 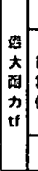 } & and & 48.1 & 58.7 & 55.6 & 58.2 & 44.7 & 68.9 & -36.2 & 56.9 & 48.1 & 60.8 & 53.5 & 101.0 & -32.0 & 90.0 & -43.9 & 68.5 & 61.2 \\
\hline & 由is & 58.7 & 58.7 & 58.8 & 58.8 & 45.4 & 71.7 & -39.1 & 58.8 & 44.1 & 50.0 & 57.0 & 120.0 & -50.0 & 118.9 & -45.4 & 51.4 & 51.4 \\
\hline & 世 NOF & 50.5 & 59.6 & 59.3 & 67.0 & 67.0 & 68.2 & -68.2 & 68.2 & 59.3 & 92.4 & 73.8 & 98.6 & 98.6 & 95.7 & -95.7 & 52.5 & 50.3 \\
\hline & 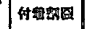 & 44.6 & - & 49.5 & 54.1 & 39.3 & 68.7 & -33.1 & 54.4 & 40.6 & - & - & - & -21.4 & $\begin{array}{lll}- & -1 \\
-1\end{array}$ & - & 1 & - \\
\hline & 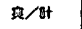 & 1.08 & 1.00 & 1.11 & 1.08 & 1.14 & 1.01 & 1.09 & 1.05 & 1.18 & 1.07 & 0.94 & 1.02 & 1.50 & 0.94 & 0.97 & 1.33 & 1.22 \\
\hline \multicolumn{2}{|c|}{ (20) } & 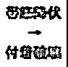 & 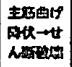 & 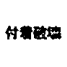 & 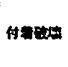 & 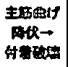 & 称 & $\begin{array}{l}\text { serst } \\
\text { Date }\end{array}$ & 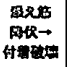 & 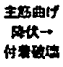 & grtex & 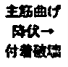 & thas & 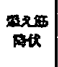 & 廿ん场 & 曲保 & 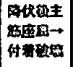 & 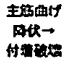 \\
\hline
\end{tabular}

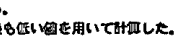
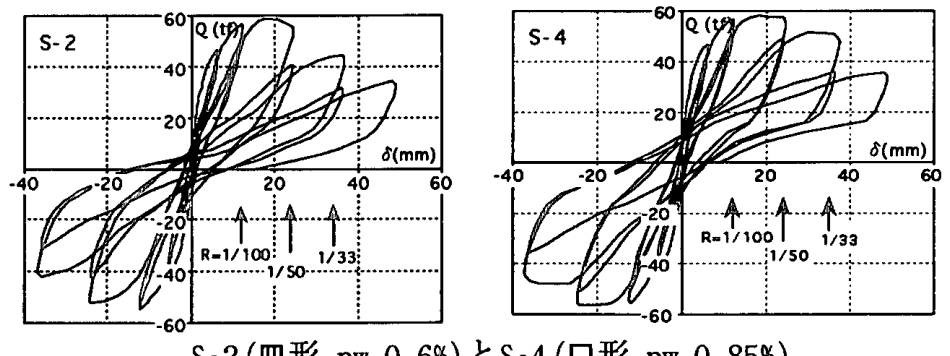

$\mathrm{S}-2$ (四形 pw $0.6 \%$ ) と $\mathrm{S}-4$ (口形 pw $0.85 \%$ )
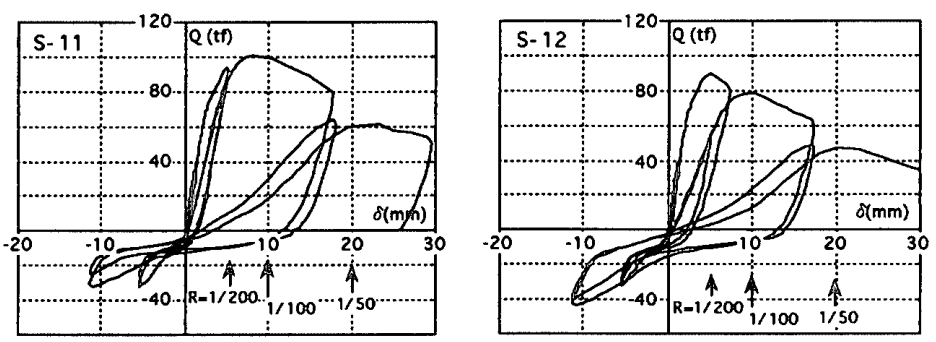

変動軸力試験体 $\mathrm{S}-11(\mathrm{PCa}), \mathrm{S}-12(\mathrm{RC}$ 継手なし)
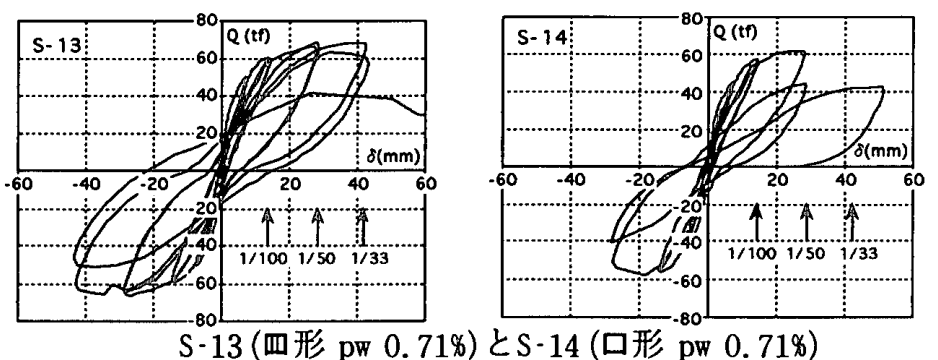

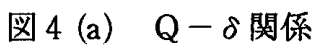
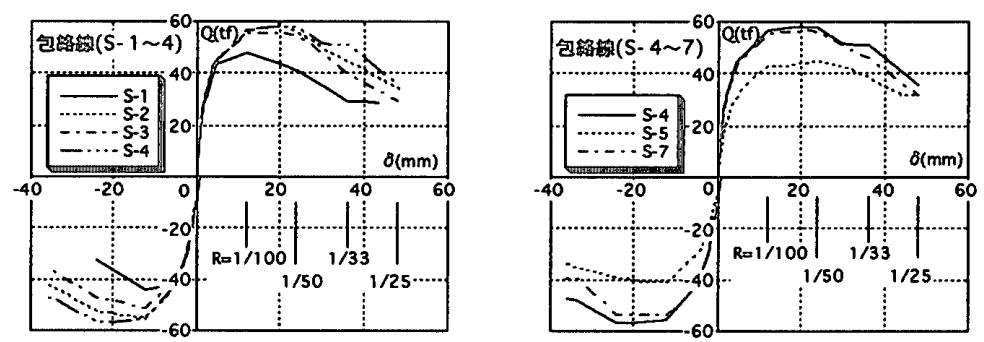

図 4 (b) Q $-\delta$ 包絡線図

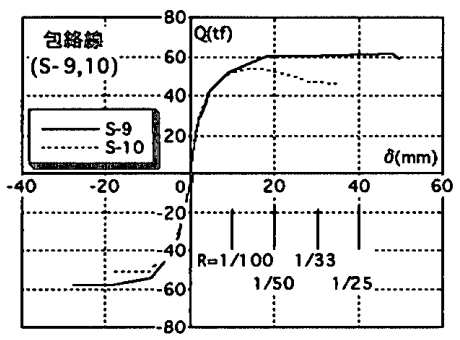


試験体の耐力性状が良いことがわかる。 副带筋を用いることによりコアコンク リートの拘束効果が向上し、付着強度が 上昇することは以前から指摘されてお り、多くの研究がなされている10)が、本 論文で対象とする構造形式でもこの副帯 筋の拘束効果により、外款とコアコンク リートの一体性が高まるため付着強度性 状が改善されると考えられる。加えて副 帯筋のダボ効果も期待できることから、 この工法における付着耐力の評価に副带 筋の効果をより大きく考慮する（あるい は副帯筋がない場合の耐力を低く評価す る）必要があることがわかる。

変動軸力下で載荷し、曲げ降伏後に付 着破壊を生じたS-6試験体は引張軸力作用 時に部材中央で添え筋が降伏し、その後 耐力が低下している。また同様に高圧縮 軸力から高引張軸力まで変動させたS 11, S-12で従来の継手のないRC柱と突合せ 継手を有するPCa柱を比較すると、図 4 (a)にQ- $\delta$ 関係を示すように、圧縮軸力時 は高強度のPCa管が有効に作用するため耐 力性状がよいが、引張軸力時は主筋に先 行して添之筋が降伏するため逆に耐力性 状が劣ることがわかる。

突合せ位置が部材中央ではないS・8試験 体は、曲げ降伏後に突合せ位置から柱端 部までの長さが短い方の主筋が付着破壊 を生じた。

\subsection{2. 付着性状}

図 5 に主筋および添え筋に貼付したひ ずみゲージから得られたひずみ分布の一 例として、図 5 (a)では軸力のない曲け破 壊を生じた同一試験体の主筋降伏時と最 大耐力時のひずみ分布を、(b) は軸力のあ る試験体の分布状況を示す。軸力のない 場合、添え筋のひずみは、部材端部危険 断面で 0 であるが、部材中央に向かって 徐々に増加し、曲げモーメントが 0 とな る中央部で引張ひずみを生じている。こ れらのひずみは中央部付近にせん断ひびわれが生じた後 に顕著になり、軸力が作用すると小さくなる傾向があ る。また、変位が小さく、鉄筋応力も低い段階では主筋 と添之筋の応力がほほ一致する区間、いわゆる平面保持 の成り立つ区間が存在するが、変形が進むにつれて主 筋、添え筋ともスパン中央まで直線分布となる傾向があ る。また主筋の降伏区間が曲け破壊試験体でも層関変形
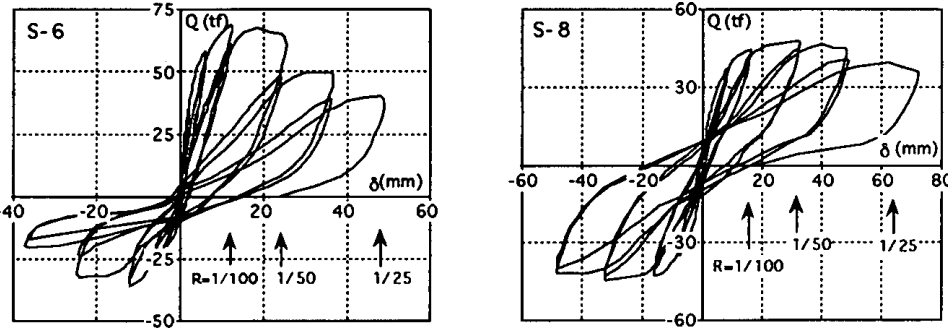

図 4 (c) その他の試験体 $\mathrm{Q}-\delta$ 関係
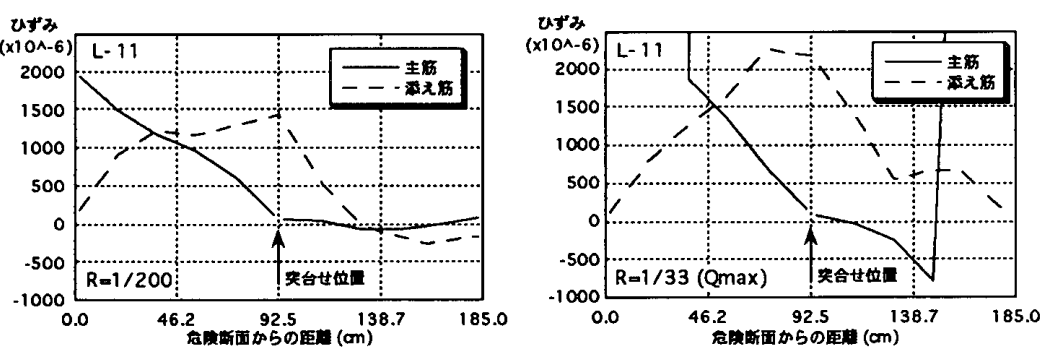

図 5 (a) 主筋・添え筋ひずみ分布（L-11試験体）
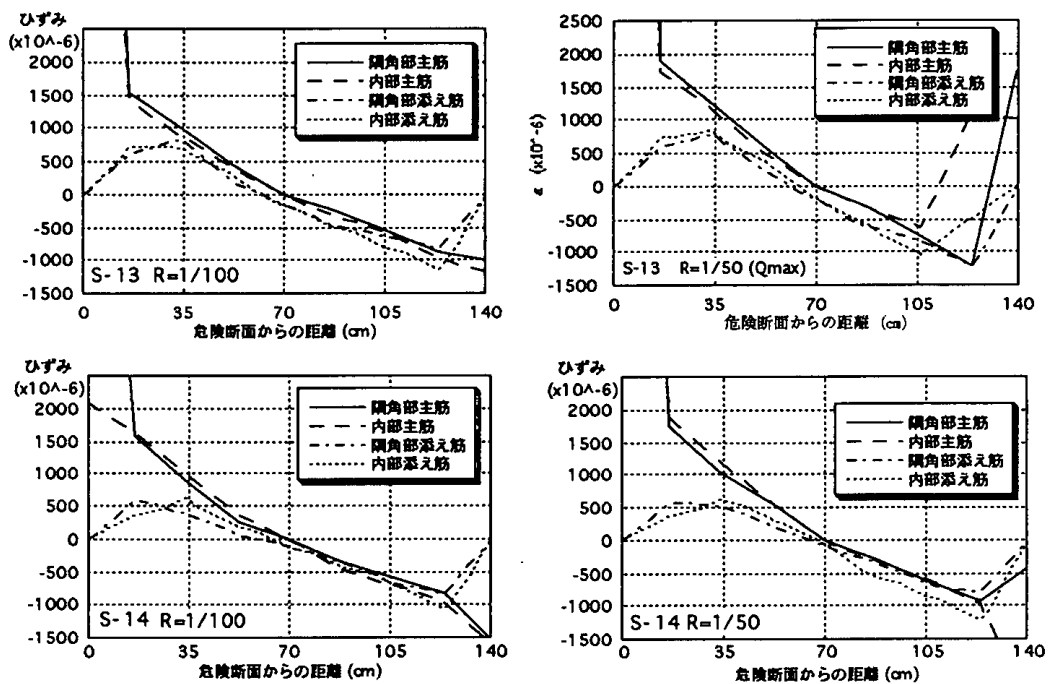

図 5 (b) ひずみ分布（中子筋の有無，隅主筋と内部主筋の比較）

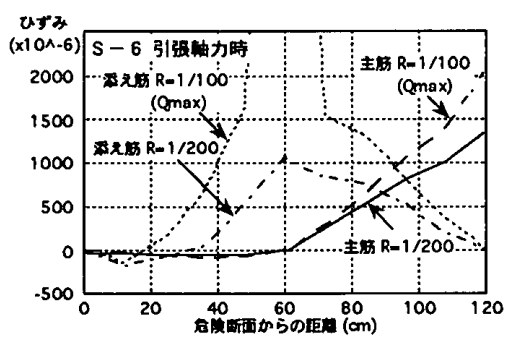

図 5 (c) ひずみ分布 (引張軸力時)

角 $\mathrm{R}=1 / 50$ で約 $\mathrm{D} / 4$ と小さいのが特 徵である。図 5 (b)のひずみ分布 では副带筋の有 無および隅角部 主筋と内部主筋

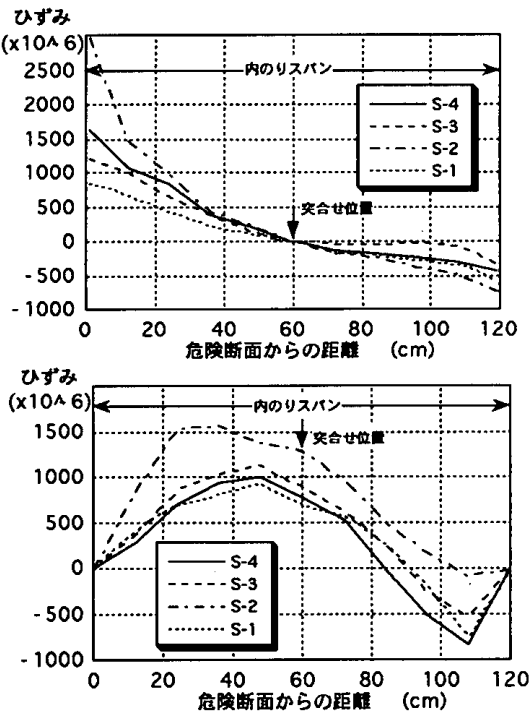

図 6 最大耐力時ひずみ分布 (上段：主筋，下段：添之筋） 

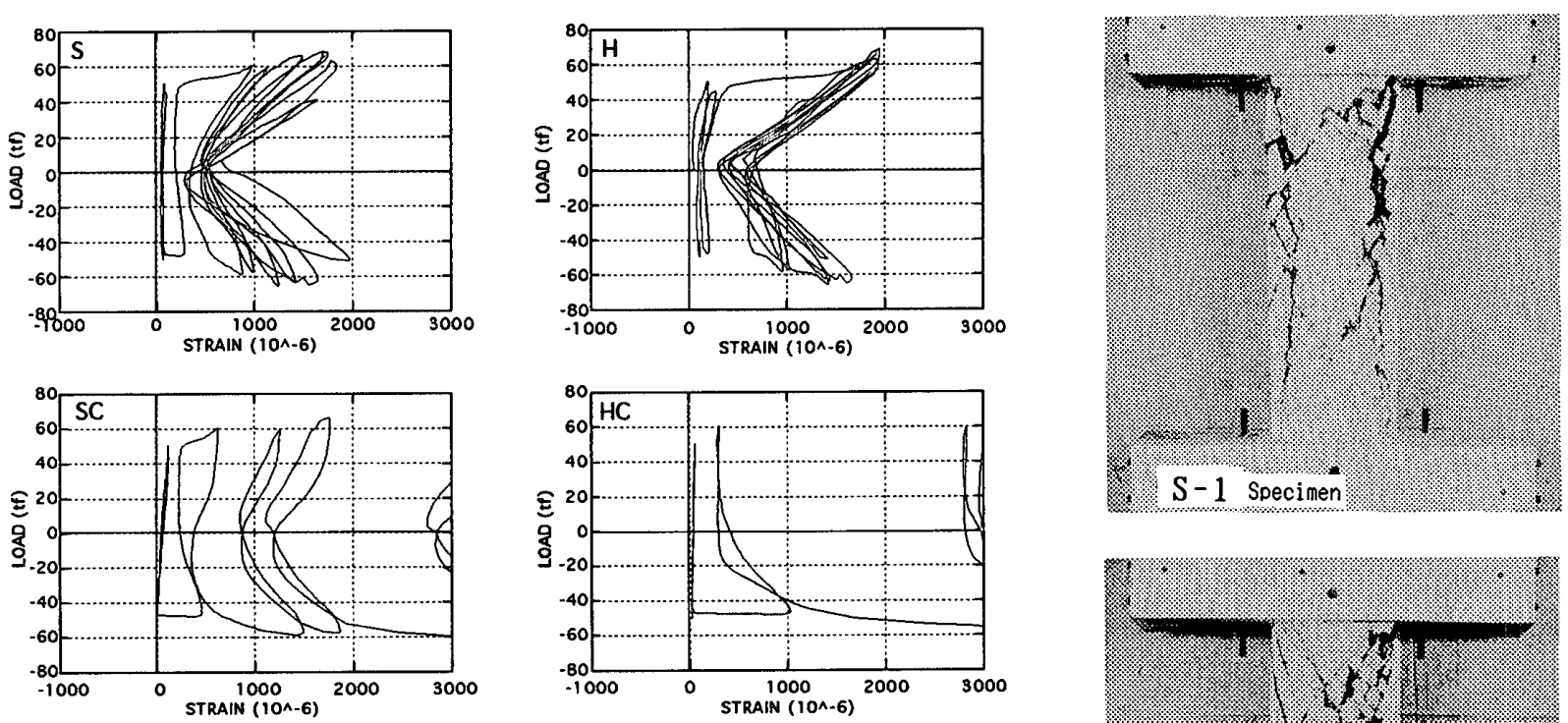

図 7 せん断補強筋のひずみ

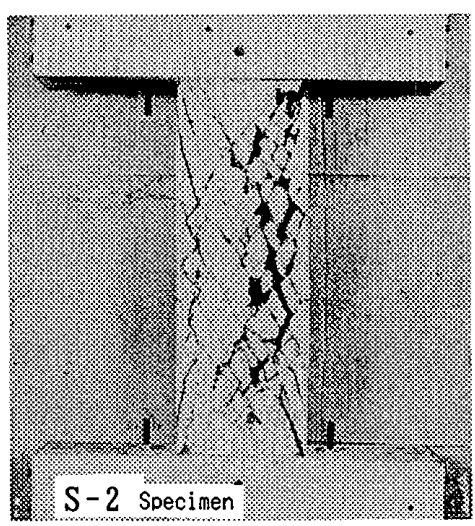

写真 1 試験体写真

を比較しているが、副帯筋の有無により添え筋のひずみ 分布に若干差が見られるものの、隅角部と内部主筋とで は殆ど差が見られない。

図 5 (c) は変動軸力試験体の弓張軸力時ひずみ分布を示 している。添え筋が引張降伏すると部材耐力か浢打ちと なっていることがわかる。

図 6 は、せん断補強筋量の違いが主筋・添え筋のひず み分布性状に及ぼす影響を調べたもので、せん断補強筋 量が多い試験体ほど同一部材角時および最大耐力時にお ける主筋ひずみ分布の勾配が大きく付着応力度が高いこ とがわかる。副帯筋を用いた場合はすでに述べたように 外殼とコアコンクリートの一体性が向上するため主筋の 最大付着強度も高い。

図 7 はS-13試験体のせん断補強筋ひずみ計測結果の一 例として、危険断面から1.4D (D:柱せい)の位置で計測し た荷重一ひずみ関係を示している。S-14も同様に計測し たが、いずれもせん断耐力計算值より低荷重でせん断補 強筋の隅角位置が曲げを伴う引張降伏を生じ、特に副帯 筋を使用していないS-14では降伏直後に最大耐力に達し ている。一方、副带筋を使用したS-13では外周筋隅角部 が降伏した後も荷重は增加したが、副带筋隅角部の降伏 に伴い耐力低下を生じている。これらの現象と前述した 隅角部主筋と内部主筋のひずみ分布に差が見られないこ
とを合わせて検討すると、ここで観察された付着破壊は 主筋を含むコアコンクリートと添え筋を内蔵する外殼PCa 管の滑りによって生じる継手破壊であると推定される。

\subsection{3ひびわれおよび破壊状況}

写真 1 に試験体の最終ひびわれ状況の一例を示す。写 真は付着破壊を生じた試験体で、主筋に沿った割裂ひび われが大きく開いているが、これらのひびわれは最大耐 力後に生じたものである。

\section{3. 耐力特性}

\section{1 各種耐力式の適用性の検討}

試験体の弾性剛性、曲げ・せん断ひびわれ荷重、曲げ 及びせん断耐力の計算值は文献5)に示される計算式を用 いて算出した。そのうち弾性剛性は外殼強度を考慮しな い計算式によっている。それぞれ図 8～図10（曲げ、せ ん断耐力の比較は表 2 および 3 ）に実験值と比較した結 果を示すが、これらの図の（実験值／計算值）の分布状 況は文献5)に示されたデー夕の分布状況とほほ同様であ ること、表 $2 ， 3$ の計算值は比較的実験值を良く捉えて いることから、添え筋を内蔵するPCa管を用いる場合も、 原則として主筋が一本もののハーフプレキャスト柱部材 の各種耐力式を適用可能であると言える。 


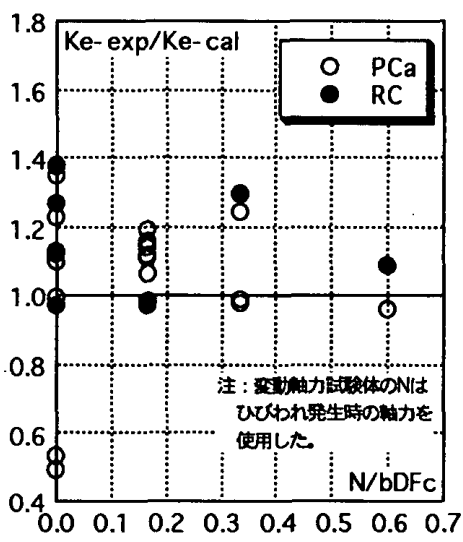

図 8 弾性剛性の（実験値／計算値） と軸力比の関係（PCa管強度を考 慮せず)

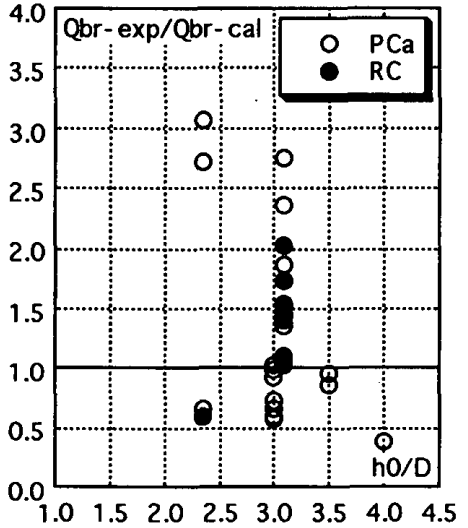

図 9 曲げひびわれ荷重の (実験值／計算值）とh0/D の関係

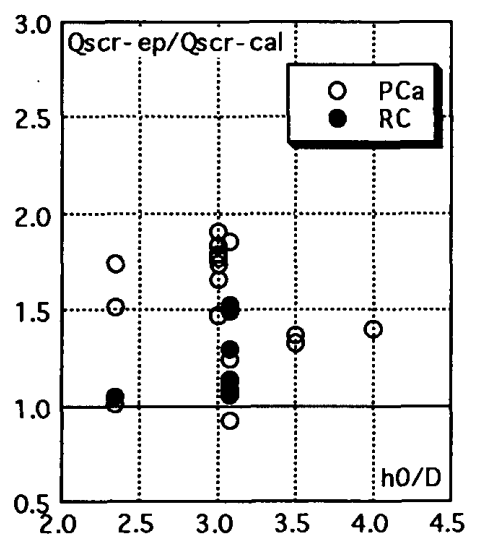

図10 せん断ひびわれ荷重の （実験值／計算值）とh0/D の関係
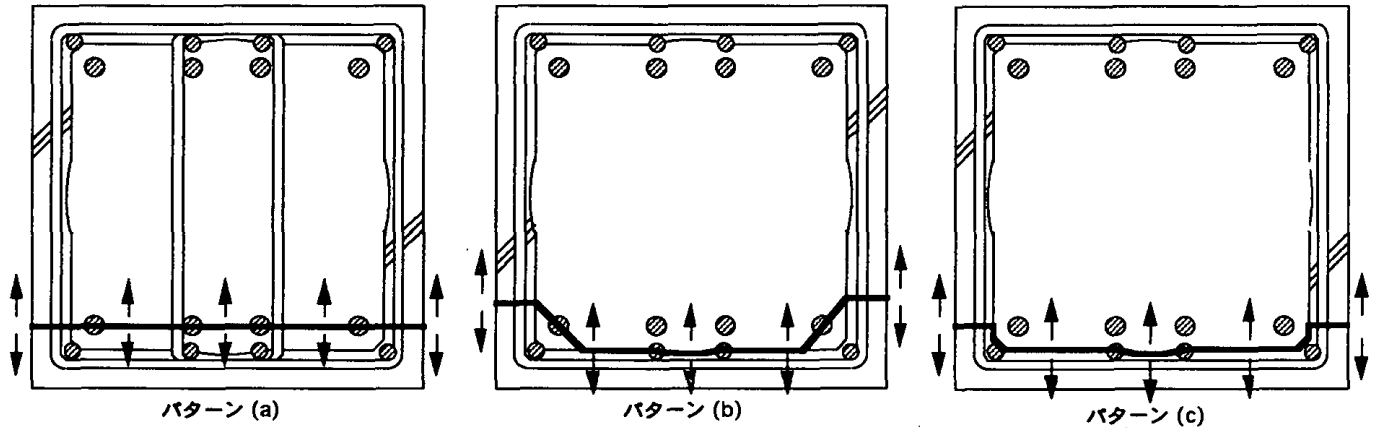

図11 割裂パターン

\section{2 添元筋応力と耐力性状の関係}

内のりスパン中央の突合せ位置では曲げモーメントが 0であることを用いて、この位置で添え筋が降伏するこ とによる最大耐力は、せん断補强筋の引張力、コンクリー トの圧縮ストラット、および添え筋の引張力によるトラ スの関係から次のように求められる。

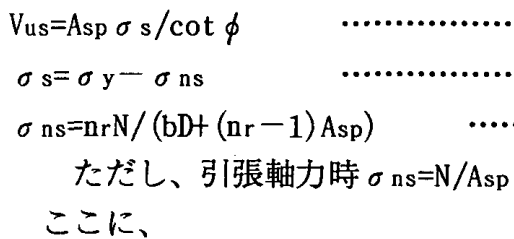

Vus: 添え筋降伏による破壇時層せん断力

$\sigma \mathrm{s}:$ 軸力を考慮した添え筋最大負担応力

$\sigma \mathrm{ns}:$ 軸力による付加応力、ただしコンクリートの引張

強度を超える場合は全軸力を添え筋が負担する。 $\mathrm{nr}$ :ヤング係数比 (=15)

Asp: 添え筋の全断面積

$\mathrm{N}$ : 軸力

b, D:それぞれ断面の幅、せい $\phi:$ コンクリートの圧縮束角度で45度とする。

以上の式では、せん断補強筋は降伏しないことを仮定 した。また、実際にはトラス機構に加えてアーチ機構も 作用していると考えられる。従って、せん断力が最大と なるように添え筋の鉄筋力をそれぞれトラスおよびアー チ機構寄与分に配分すべきであるが、簡便でかつ安全側 の評価となるように、添え筋の鉄筋力は全てトラス機構 に寄与するものとした。さらに引張軸力が作用した場合、 コンクリートの引張強度を無視し、全軸力を添え筋が負 担するとしている。

軸力のない実大試験体 $\mathrm{L}-2,3,4$ で添え筋降伏俊に若干の 耐力上昇が観察されたが、これらの試験体は主筋の降伏 が先行しており、主筋と添え筋のひずみ効果の影響が表 れたものと推定される。また小型の引張軸力を作用させ た試験体 (S-6,S-11)では、添え筋が降伏するとその後の 耐力上昇がほとんどなかった。表 3 中の変動軸力試験体 の引張軸力時計算值は上式による計算結果を示している。

\section{3 付着耐力}

$\mathrm{PCa}$ 管を用いた試験体の付着破壊タイプは載荷終了時の 
試験体の状態から、図11 (a)に示すように外款とコアコン クリートが一体となって全割裂を生じるもの、同図(b)に 示すように外款PCa管の割裂とコアのコーナー割裂、外殼 とコアの界面付着破壊によるもの、同図 (c)に示す、外款 の割裂にともなう界面付着破壊による継手破壊の 3 通り が推定された。(a) (b) タイプの破壊は継手のないPCa試験 体5)で観察された割裂パターンである。このうち軸力の ない試験体では、最大耐力後に隅角部コンクリートを含 むコアコンクリートがPC管から抜け出す現象が観察され たことから、明らかに(c)タイプの破壤を生じたと考えら れる。軸力のある試験体では判別が困難であったが、 2.3.2項で述べた現象やひびわれ発生状況から判断すると (c) が生じて耐力低下後にコアコンクリートの割裂を生じ るものと思われ、最大耐力は (c) タイプで決まると推定さ れる。以下に (c) タイプの割裂強度すなわち最大耐力時主 筋付着強度について検討する。この主筋付着強度は (5) 式 で示すようにコンクリートの割裂強度と拘束筋の補強効 果による強度上昇の和として求められると仮定している。 また文献5)では繰り返しによる強度低減俰数 $\alpha$ を採用して いるが、 $\alpha$ は鉄筋とコンクリート間の付着特性を検討し た文献6)に基づく係数であり、コアコンクリート全体が 抜け出す継手破壇には適用できないと考えられる。

(1)コンクリートの割裂強度

コンクリートの割裂強度は日本建築学会「鉄筋コンク リート造建物の終局強度型耐震設計指針・同解説」（以 後終局強度型指針と省略する）におけるコンクリートの 割裂強度式を準用した。

すなわち外款とコアコンクリートの界面付着を無視し、 $\mathrm{PCa}$ 管に設けたシアコッターの付着抵抗は考慮しない条件 のもとで外款コンクリートの割裂強度のみで評価するこ ととした（式(6)）。

(2)せん断補強筋の補強効果による付着強度上昇

せん断補強筋の補強効果に関する考え方は文献5) と同様 で式 (7)を基本とする。一体打ち試験体の付着割裂強度は 式 (7)で外款厚さを 0 として算出した。

PCa管を用いる場合、2.3.2項のひずみ計測結果から得 られたように隅角部と内部主筋の付着強度を別々に求め るのではなく、部材の最大耐力時にはすべての主筋の付 着強度は等しいとして求め、同時に $\tau$ buに及ほすせとん断補 強筋の降伏強度の影響を考慮する必要があると考えられ る。図12は付着破壊を生じたPCa試験体を対象に、最大耐 力時主筋付着强度の実験值 $\tau$ bu-expから $\tau$ co（計算值）を 引いた值（ $\tau$ st'）と、 (pw $\sigma$ wy $)$ の関係、および $\tau \mathrm{st}^{\prime}$ と式 (7)中のコンクリート強度に関する項、せん断補強筋の拘 束に関する項との関係をそれぞれ調べたもので、図中の 直楾は最小二乗法による近似直線である。同図からこれ ら各項目がて st’とほほ比例関係にあることがわかる。 デー夕数が少なく使用した補強筋の降伏強度、補強筋形
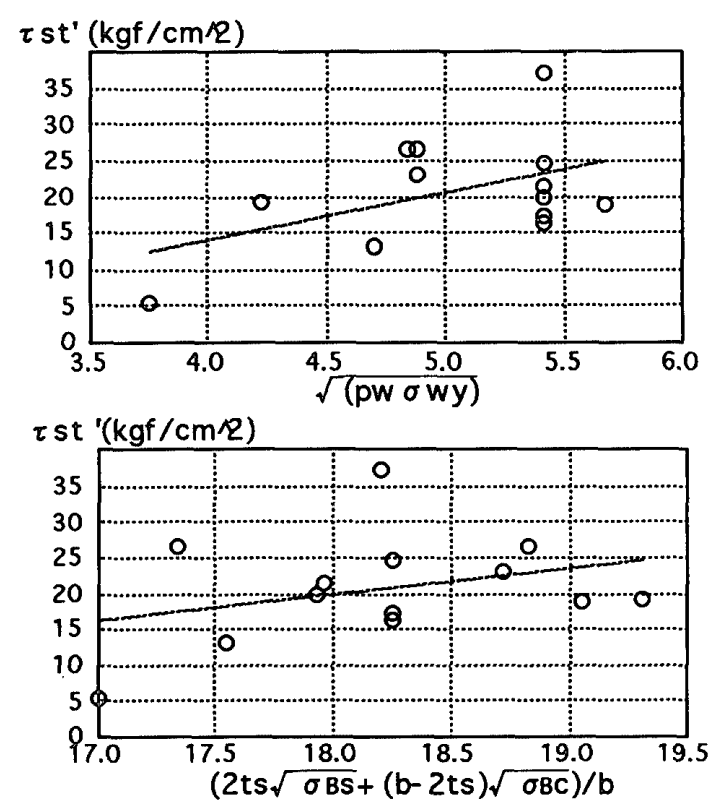

$\tau \mathrm{st} \mathrm{I}^{\prime}(\mathrm{kgf} / \mathrm{cm} / 2)$

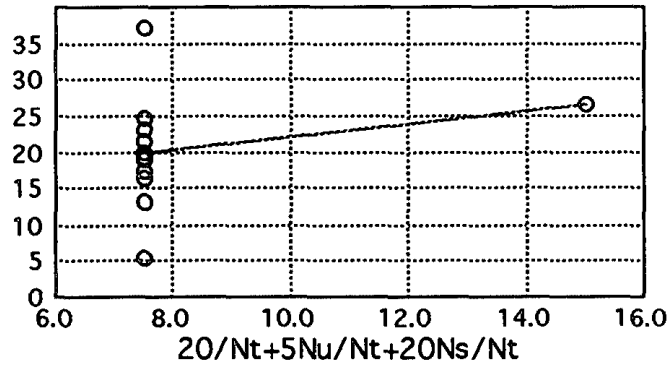

図12 $\tau$ st'に及ほす要因の検討

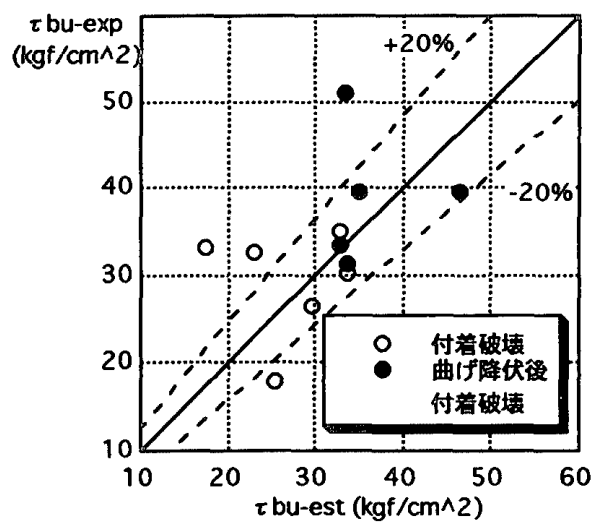

図13 $\tau$ bu実験值と計算値の比較

状が非常に限られた範囲であるが、せん断補強筋の降伏 強度を考慮する項として式(7)のpwに代えて $「(\mathrm{pw} \sigma \mathrm{wy})$ を 用い、 $\tau$ st' との一致性を考慮して決定した係数 $(1 / 600)$ を 乗じるとで $\tau$ stを評価することができる（式 $(8) ） 。$

$$
\begin{aligned}
& \tau \mathrm{bu}=\tau \mathrm{co}+\tau \mathrm{st} \\
& \tau \mathrm{co}=(0.8 \mathrm{ts} / \Sigma \mathrm{db}+0.5) \sqrt{\sigma \mathrm{Bs}} \\
& \tau \mathrm{st} 1=\left\{\left(20 / \mathrm{Nt}+5 \mathrm{Nu} / \mathrm{Nt}_{\mathrm{t}}+20 \mathrm{Ns}_{\mathrm{s}} / \mathrm{Nt}\right) \mathrm{pw}(2 \mathrm{ts} \sqrt{\sigma \mathrm{Bs}}+\right. \\
& (\mathrm{b}-2 \mathrm{ts}) \sqrt{\sigma \mathrm{Bc}})\} / \mathrm{db}
\end{aligned}
$$


$\tau s t=\left\{\left(20 / \mathrm{Nt}+5 \mathrm{Nu} / \mathrm{Nt}+20 \mathrm{Ns} / \mathrm{Nt}_{\mathrm{t}}\right) \sqrt{\mathrm{pw} \sigma \mathrm{wy}} / 600 \cdot\right.$

$$
(2 \mathrm{ts} \sqrt{\sigma \mathrm{Bs}}+(\mathrm{b}-2 \mathrm{ts}) \sqrt{\sigma \mathrm{BC}})\} / \mathrm{db}
$$

ここに、

pw, $\sigma$ wy: せん断補強筋比及びせん断補強筋降伏強度 $\sigma \mathrm{Bs}, \sigma \mathrm{BC}$ ：それぞれ外款、コアコンクリート強度 $\mathrm{db}$ :隅角部の主筋直径

$\Sigma \mathrm{db}$ :一列に並ふ主筋直径の総和

$\mathrm{Ns}, \mathrm{Nu}$ : それぞれ一列の主筋のうち直接副带筋のかかっ

ているものといないものの本数。

$\mathrm{Nt}:$ 一列の全主筋本数 $(\mathrm{Nt}=2+\mathrm{Ns}+\mathrm{Nu})$ 。

$\mathrm{ts}: \mathrm{PCa}$ 管の厚 d

表 2 及び 3 の付着耐力計算值は上式による $\tau$ bu計算値を 用いて、部材端部で主筋応力を算出し $(\sigma=\tau$ bu $\cdot \psi \cdot h /$ 2）、断面解析による主筋応力と一致する時点の耐力を算 出して実験値と比較している（ただし $\sigma>\sigma \mathrm{y}$ となる時 は”一”を記入している）。曲げ破壊を生じなかった試 験体の計算結果は主筋径、軸力にかかわらず精度良く実 験結果を捉えており、各試験体の破壊モードも一致して いる。また図13は実験值 $(\tau$ bu-exp) と計算值 $(\tau$ bu-est $)$ を 比較したものである。

\section{4. 部材靬性の評価}

本論文で対象としている構造形式においては付着に対 する設計法を確立することが不可欠であるといえる。特 にぜい性的な付着破壇を避けるため、せん断補強筋量、 コアコンクリート強度等を絵合的に評価し、部材に欲求 される性能を確保できるような設計法の確立が望まれる。

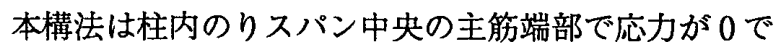
あるので、例えば部材の曲げ降伏に必要な主筋の付着応 力度 ( $\tau$ by) は (9) 式で与えられるなど、部材酎力と付着強 度の関係を比較的捉えやすい。これを用いて、付着破壊、 曲げ降伏後の付着破壊、曲げ破壊を生じた各試験体を付 着強度と変形能の関係で捉えることを試みる。図14は軸 力が $1 / 3 \mathrm{FcbD}$ 以下のPCa 試験体を対象に、 $\tau$ byに対する $\tau \mathrm{bu}$ 実験值（最大耐力時の付着強度で主筋の降伏域を除いた もの）の比を縦軸に、横軸に各試験体の最大耐力時層間 変形角をとって示したものである。また図中の矢印は ジャッキのストローク等実験上の都合で決まった最大変 形角で、未だ最大耐力に至っていないことを示している。

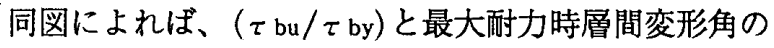
間には強い相関が見られ、矢印付き試験体を除く最小二 乗法による近似（図中破線）の相関係数は $\gamma=0.71$ であっ た。また同図より $1.0<(\tau$ bu $/ \tau$ by $) \leqq 2.0$ の範囲に曲 げ降伏後に付着破壊を生じた試験体が集中している。 以上から降伏ヒンジを計画する柱では、R>1/100で $\tau$ bu/ $\tau$ by $>2.0$ を確保するように、図14中に直線で示し

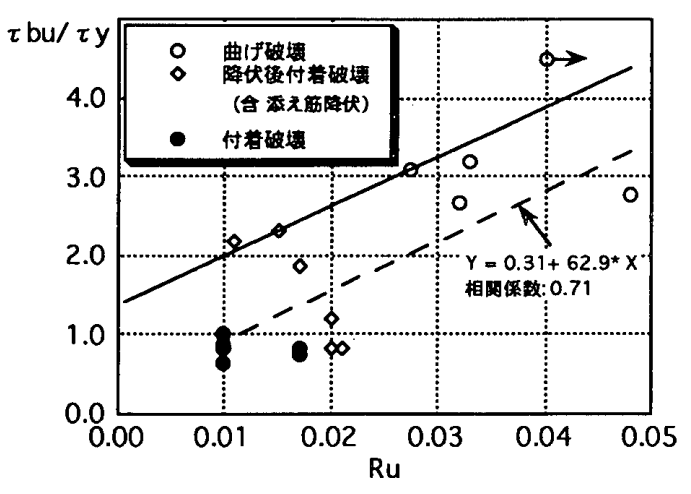

図14 付着強度比と変形能の関係

た近似式を平行移動した (10) 式で部材終局時層間変形角 に対応する必要付着強度を算定する設計法が一例として 考えられる。

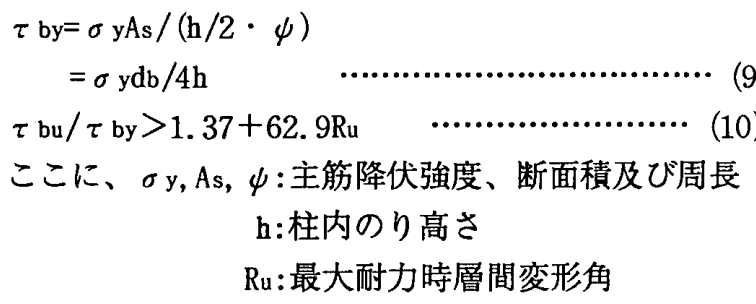

ここに、 $\sigma \mathrm{y}, A \mathrm{~s}, \psi$ : 主筋降伏強度、断面積及び周長 $\mathrm{h}:$ 柱内のり高さ $\mathrm{Ru}$ :最大耐力時層間変形角

\section{5. 結論}

本研究により以下に示す知見が得られた。

(1) PCa管を用いた突合せ継手試験体は同一せん断補強筋 量であれば副帯筋（中子筋）を使用するほうが外款とコ アコンクリートの一体性が向上することにより付着性状 が優れる。

(2) 部材の曲げおよびせん断耐力はPCa管の強度を考慮す る継手のない場合の提案式によって求められる。

(3) 逆対称載荷ではモーメントが 0 となる部材中央で添え 筋に引張ひずみが生じ、添え筋が部材中央付近で降伏す ると部材の耐力上昇が望めなくなる。この現象は、軸力 とせん断ストラットの材軸方向成分によると考えられ、 添え筋を降伏させない設計が必要である。

(4)付着破壊試験体は本構造形式特有の外殸とコアが一体 性を失う割裂パターンを生し、、主筋と添え筋間に応力伝 達がなされなくなる一種の継手破壊によって耐力が低下 したと考えられる。

(5) 添え筋降伏による破壊耐力、付着割裂破壊耐力の算定 方法を提案し、本実験結果との対応性が良いことを確認 するとともに、部材の鞁性を考慮した付着設計法を提案 した。

(6) 突合せ継手部材の曲げおよびせん断耐力はPCa管を使 
用した継手のない部材の耐力式で評価可能である。

\section{期辞}

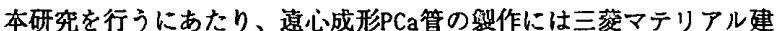
材検のご協力を得た。記して感揤の意を表します。

\section{参考文献}

1)增田安彦，吉岡研三，脇坂達也:添之筋を用いた太径異形铁笳継手に閂 する研究, コンクリート工学詥文集, Vol 1, No. 1,pp. 91～103, 1990年 7 月

2)增田安彦, 吉岡研三,脇坂達也: 突合せ式重ね縫手を有するハーフブレ キャスト柱部材に関する研究，コンクリート工学年次論文報告 集, Vol. 14, No. 2, pp. 113 118, 1992年

3) 增田安彦.吉岡研三:突合せ式重ね継手を有するハーフブレキャスト柱 部材の酎力性状に関する研究, コンクリートエ学年次諭文竍告 急, Vol. 16, No. 2, pp. 113 118, 1994年 4) 六車熙, 渡辺史夫:铁筋コンクリート柱のせん断抵抗渽等に関する研
究，日本建築学会構造系論文報告集，No. 341, pp. 11 18，1984年7月 5) 增田安彦, 吉岡研三:外毅に薄肉ブレキャスト管を使用した鉄筋コン クリート柱の耐力特珄に関する研究，日本建築学会構造系詥文報告 奥, No. 458,pp. 109 118，1994年4月

6) 㚞田司郎，角徽三: 緗り返し荷重下における鉄筋とコンクリート間の付 着特性に関する研究, 日本建筑学会論文報告集, No. 229, pp. 15 24, 昭 和 50 年 3 月

7)增田安店, 吉岡研三, 脇坂達也:太径異形鉄筋の重小継手に関する研究 その 4) 突き合わせ継手工法の開発、日本建䇣学会大会学術講演梗概 集, pp. 681 682, 1990年6月

8) 增田安彦, 吉网研三, 脇坂達也:太径異形鉄筋の重ね継手に関する研究 その 6) 突き合わせ継手工法の開発, 日本建築学会大会学術講演梗概 集, pp. 337 338, 1991年9月

9) 增田安彦, 吉岡研三, 脇坂達也:太径異形鉄笳の重ね継手に閵する研究 その 8) 实き合わせ縋手工法の開発, 日本建淛学会大会学術㒛演梗概 集, pp. 947 948, 1992年8月

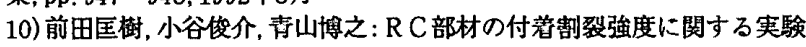
的研究. コンクリート工学年次論文報告集, Vol 13, No.2, pp. 145 150,1991 年 